(С) М.Д. Тукало, 2011

ISSN 2076-8184. Інформаційні технології і засоби навчання. 2011. №4 (24).

Режим доступу до журналу: http://www.journal.iitta.gov.ua

УДК 371.315.2, 372.854

Тукало Марія Дмитрівна, молодший науковий співробітник Інституту інформаційних технологій і засобів навчання Національної академії педагогічних наук України, м. Київ, e-mail: maria.tukalo@ mail.ru

\title{
СУЧАСНІ ІННОВАЦІЙНІ ПЕДАГОГІЧНІ ТЕХНОЛОГІЇ НА УРОКАХ ХІМІЇ В ПРОФІЛЬНІЙ ШКОЛІ
}

\section{Анотація}

Стаття дає характеристику сучасних інноваційних педагогічних технологій за способом їх застосування на уроках хімії в профільній школі, розкриває значення їх в навчальному процесі $з$ метою оптимізації засвоєння й закріплення знань і вмінь, застосування їх для розв'язання конкретних завдань, формування наукових переконань, посилення творчої активності з переходом від пізнавальної мотивації до професійної через створення комплексу умов для розвитку творчого потенціалу учнів 3 використанням комп'ютерно орієнтованих засобів навчання в рамках сучасної педагогічної системи з метою реалізації основних навчальних цілей: розвивальної, інформаційної, мобілізаційної, комунікативної, дослідницької.

Ключові слова: комп'ютерно орієнтовані засоби навчання, комп'ютерні телекомунікації, інноваційні педагогічні технології, метод проектів.

Актуальність дослідження цієї теми полягає у визначенні оптимальних і ефективних методів і технологій під час вивчення хімії в профільній школі для посилення мотивації й активізації навчального процесу.

Аналіз опрацьованих джерел $[2,3,5,7,8,9,12,13]$ показав, що сучасні інноваційні педагогічні технології сприяють створенню інноваційної педагогічної системи, в основі якої навчальний процес будується на принципах гуманізації, демократизації, диференціації та індивідуалізації, що $є$ невід'ємною складовою профільного навчання.

Метою цієї статті $є$ пошук і аналіз ефективних педагогічних технологій 3 використанням комп'ютерно орієнтованих засобів навчання на уроках хімії профільної школи. 
Концепція модернізації сучасної освіти передбачає введення профільного навчання в старшій школі. Основна ідея оновлення освіти полягає в тому, що навчання має стати більш індивідуалізованим, функціональним та ефективним.

Серед шкільних предметів хімія займає своє особливе місце. Основи хімії - це система загальних знань про елементи, речовини, процеси їх перетворень і методи їх пізнання, побудована на базі провідних ідей, теорій i досягнень хімічної науки. Відповідно до принципів дидактики формулюються загальні цілі навчання хімії, обираються методи і засоби розв'язання навчальних завдань. Важливою особливістю навчання хімії в профільній школі є тлумачення ії як загальнокультурної цінності й інструменту пізнання навколишнього світу і самого себе. Профільне навчання за своєю ідеєю передбачає суттєве посилення самостійної пізнавальної і практичної діяльності учнів з використанням активних методів навчання [2, 6].

Методика викладання хімії в профільних класах (особливо на елективних курсах) має на меті поступовий розвиток в учнів розумової праці й самоосвіти. Основною функцією вчителя при цьому є координація учня в його пізнавальній діяльності, корекція отриманої інформації, аналіз і актуалізація знань в навчальному курсі.

Учитель профільної школи має бути не лише спеціалістом високого рівня свого профілю , але й повинен забезпечувати:

-варіативність і особистісну орієнтацію навчального процесу, проектування індивідуальних навчальних траєкторій;

-практичну орієнтацію навчального процесу із застосуванням інтерактивних компонентів;

-закріплення профільного самовизначення старшокласників і формування в них здібностей і компетентностей, необхідних для продовження навчання у відповідній сфері професійної освіти [5].

Тому сучасний освітній процес немислимий без пошуку нових, більш ефективних технологій, що сприяють розвитку творчих здібностей учнів. Необхідною умовою $є$ те, щоб учень став активним учасником навчального процесу, а вчитель був організатором його пізнавальної діяльності [8]. Самостійно знайдена відповідь - це маленька перемога дитини в пізнанні складного світу природи, що надає впевненості у своїх можливостях, створює позитивні емоції, усуває неусвідомлений опір процесу 
навчання. Водночас учень самостверджується як особистість. Так формується інтерес не просто до предмета, а й до самого процесу пізнання - пізнавальний інтерес.

У своїй професійній діяльності вчитель хімії має використовувати знання психолого-педагогічних і хімічних дисциплін, філософії; різних аспектів формування мети навчання хімії; взаємозалежності дидактичної мети уроку і його компонентів; функцій і можливостей хімічного експерименту, аудіовізуальних засобів i комп'ютерних програм; прийомів організації пізнавальної діяльності учнів і керування цією діяльністю; завдань, змісту, методів і організаційних форм навчання хімії; форм і видів контролю, методичних прийомів оцінювання рівнів навчальних досягнень [1, 6]. Методи навчання - один 3 основних компонентів навчальновиховного процесу, спосіб керування й активізації пізнавальної діяльності учнів.

За Хуторським А. В., педагогічні інновації, як методи навчання, діляться на різні типи і підтипи $[11,12]$. Так, відносно особистісного становлення суб'єктів навчання в галузі розвитку певних здібностей учнів, їх компетентностей, розрізняють такі педагогічні технології:

- технологія проблемного навчання;

- технологія різнорівневого навчання;

- технологія ігрового навчання;

- інформаційно-комунікаційні технології;

- технології інтегративного навчання;

- проектні технології;

- освітня рефлексія учнів.

Використання таких освітніх технологій сприяє розвитку пізнавальних i творчих інтересів у учнів.

Уведення профільної старшої школи і навчання дітей, що здійснили свій вибір і мають стимул і певний потенціал, передбачає новий рівень засвоєння знань, розвиток пізнавальних інтересів, інтелектуальних і творчих здібностей. Профільне навчання слід розглядати як один із напрямків реалізації особистісно зорієнтованої стратегії освіти. Саме такий підхід можна здійснити, скориставшись технологією проблемного навчання. 
Проблемне навчання - це спосіб широкого охоплення явищ, що має на меті розвиток навчальних проблемних завдань (які не мають однозначної відповіді), самостійного пошуку знань і набуття досвіду їх використання.

На уроках хімії проблемна технологія розглядається насамперед як особливий вид пізнавальної активності, мотивований проблемним протиставленням відомого й невідомого, що має на меті активізацію процесу пізнання й осмислення нового [9].

Проблемне навчання пронизує весь курс хімії, особливо в профільній школі, де більшість уроків можна інтенсифікувати через постановку й вирішення проблемних завдань. Слід зазначити, що більш доцільними проблемні уроки є в 10-11 класах. Учням пропонується проблема, яку вони розглядають 3 позицій оптимістів, реалістів або песимістів. Для проведення таких занять необхідно планувати спарені уроки. На першому уроці здійснюються організаційні заходи, ставиться певна проблема: наприклад, відкриття радіоактивності і його наслідки з позитивної і негативної точки зору. На другому уроці кожна команда відповідно до своєї назви «Оптимісти», «Реалісти», «Песимісти» повинна розглянути аспекти цієї проблеми.

Керуючись програмним матеріалом 3 хімії, можна запропонувати конкретні приклади застосування проблемної технології.

Так, наприклад, під час вивчення основ загальної хімії ключовим поняттям у системі знань щодо речовини $е$ поняття «хімічний зв'язок». Формування його базується на основі понять «валентність» i «ступінь окиснення». Але виникає проблема: поняття «валентність» можна застосовувати лише для сполук 3 ковалентним зв’ язком. Валентність не буває від’ємною і не може дорівнювати нулю. Тому більш універсальним є поняття «ступінь окиснення», яке поширюється і на сполуки з йонним зв’ язком.

Низка проблемних питань, що пробуджують зацікавленість в учнів до наукового сприйняття світу, виникає також під час вивчення окремих тем курсу органічної хімії.

Зокрема, згідно теорії хімічної будови органічних сполук О. М. Бутлерова Карбон у всіх органічних сполуках чотиривалентний. Проблемним завданням тут $\epsilon$ визначення валентності Карбону в насичених вуглеводнях: етан, пропан, бутан, пентан, гексан, гептан. Учні приходять до висновку, що використання традиційного способу визначення валентності суперечить складу запропонованих вуглеводнів, й 
успішно сприймають інформацію про структурну і просторову будову органічних сполук і здатність атомів Карбону сполучатись між собою.

У процесі вивчення ароматичних вуглеводнів постає суперечність між хімічною поведінкою бензену i його структурною циклічною формулою, запропонованою Кекуле, оскільки експериментально не підтверджується його ненасиченість, тобто наявність подвійних зв’ язків.

У свою чергу, кислотні властивості фенолу учні можуть передбачати, виходячи з будови його молекули, враховуючи взаємний вплив груп атомів і спираючись на отримані знання про будову бензольного кільця.

Навчальну проблему можна поставити і в розгляді відношення багатоатомних спиртів до лугів порівняно з одноатомними спиртами, базуючись на тому, що учням уже відомо, що одноатомні насичені спирти за нормальних умов 3 лугами не реагують.

Під час вивчення вуглеводів має місце проблемне питання стосовно пояснення різної хімічної поведінки глюкози і фруктози, що мають однакові молекулярні формули, але різні хімічні властивості. Цікавою особливістю для учнів тут є те, що фруктоза, на відміну від глюкози, не є альдегідом і тому не дає реакції «срібного» дзеркала.

Не менш цікавою $\epsilon$ навчальна проблема щодо передбачення хімічних властивостей амінокислот у процесі аналізу їх загальної хімічної формули i функціональних груп, що для них характерні.

Отже, проблемна технологія на уроках хімії - це особливий вид навчальної активності учнів, що оперує протиставленням відомого й невідомого і має на меті активізацію процесу пізнання.

Технологія різнорівневого навчання є також актуальною, оскільки ефективна організація освітнього процесу неможлива без використання індивідуальнодиференційованого підходу до учнів. У навчанні хімії диференціація має особливе значення. Це обумовлено специфікою навчального предмета, оскільки учні порізному сприймають навчальний матеріал: для деяких учнів засвоєння хімії пов'язане зі значними труднощами, а інші наділені яскраво вираженими здібностями до вивчення предмета. Тому проблему міцності знань 3 хімії можна розв'язати через 
технологію рівневої диференціації, що орієнтована на введення трьох стандартів у організації навчальної діяльності:

- обов'язкової загальноосвітньої підготовки (рівень, якого повинен досягти кожен учень): засвоєння знань в рамках навчальної програми;

• підвищеної підготовки, тобто з поглибленим засвоєнням змісту навчального предмета;

• навчання на рівні поглибленого вивчення предмета для здібного учня [3].

Навчальний процес відбувається на індивідуальному максимально можливому рівні складності. Учень самостійно визначає напрям власної реалізації на підставі наявних здібностей, уподобань, інтересів і вибирає ту освітню траєкторію, яка йому найбільш імпонує. До самостійного вибору завдань учнів потрібно готувати, радити, яке завдання вибрати, але право вибору завжди залишається за ним, оскільки вивчення кожного предмета в школі - не мета, а засіб розвитку дитини. Для оцінки результатів освітньої діяльності необхідно встановити рівень засвоєння матеріалу: рівень відтворення фактів, їх реконструювання чи варіативний рівень (рівні розумових операцій) [8].

Прикладом такої різнорівневої орієнтації є схема перевірочної самостійної роботи у 8-му класі за темою «Основні класи неорганічних сполук».

Варіант 1. (Включає завдання дослідницького рівня пізнавальної діяльності учнів).

Скласти формули гідроксидів, яким відповідають такі оксиди:
А) літій оксид;
Б) алюміній оксид;
В) карбон(IV)оксид.

Варіант 2. (Включає завдання частково-пошукового рівня пізнавальної діяльності учнів).

Скласти формули оксидів за їх назвами:
А) манган(IV)оксид;
Б) ферум(III)оксид;
В) сульфур(VI)оксид.

Варіант 3. (Включає завдання репродуктивного рівня). 
За сучасною номенклатурою дати назви таким оксидам (пропонуються формули оксидів).

Отже, методика індивідуально-диференційованого підходу до вивчення хімії сприяє ефективності, індивідуалізації і гуманізації навчального процесу.

Певне місце в системі методів навчання має технологія ігрового навчання, що включає імітаційні ігри, які відтворюють реальну або гіпотетичну ситуацію. Поняття «імітаційна гра» охоплює і більш вузькі поняття: ділова гра, рольова гра, операційна гра, метод інсценування з використанням консультантів і педагогічних програмних засобів для персональних комп'ютерів [6].

Ця технологія сприяє підвищенню інтересу учнів до різних видів навчальнопізнавальної активності. Гру, як метод навчання, передавання досвіду старших поколінь молодшим, люди використовують здавна. На уроках хімії ігрові технології повинні посідати своє чинне місце, оскільки введення дидактичних ігор є засобом створення на уроках таких ситуацій, що збуджують думку і стимулюють творчу ініціативу, а особливістю гри $є$ створення умов, не властивих традиційному навчанню. Надаючи учням свободу інтелектуальної діяльності, учитель спрямовує їх до створення проблемних ситуацій i пошуку шляхів розв'язання через уміло організовану пошуково-дослідницьку самостійну роботу. Окрім використання ігрових ситуацій, можна практикувати ще й такі нетрадиційні уроки, як: мандрівка, конференція, суд, ділова гра, КВК, семінар, диспут, брифінг тощо. Такі уроки доцільно планувати під час актуалізації знань, вивчення нового матеріалу, його закріплення, повторення. Так, наприклад, хімічний КВК - форма змагання між 2-3 класами однієї паралелі. Завдання поділяються на домашні і класні. Основна мета розвити інтерес до предмета через гру, згуртувати колективи учнів, перевірити засвоєння матеріалу за певний проміжок часу [6].

Завдання можуть бути хімічними і розважальними.

Хімічні:

- хімічний калейдоскоп (номенклатура і класи сполук);

- хімічний паровозик (рівняння реакцій для здійснення перетворень);

- хімічні вікторини;

- пересувна хімчистка (дослідним шляхом виведення плям чорнила, зелені, кави, соків тощо з використанням мінімального набору хімічних засобів). 


\section{Розважальні:}

- створення реклами й антиреклами;

- конкурси на кращу хімічну замальовку, ребус чи кросворд;

- творчі веселі сценки, як «Алхімічна лабораторія - екскурс у минуле».

Отже, ігрова модель навчання, крім основної дидактичної функції, надає можливість у самовизначенні учня, розвиває його творчу уяву, сприяє формуванню навичок співпраці, дозволяє вільно висловлювати власну думку, зайняти певну позицію. Таке навчання заохочує учнів до оволодіння основами хімічних знань, посилює ініціативу, сприяє роботі з науково-популярною літературою, у доступній формі інтегрує знання з природничих дисциплін.

Використання ж інформаційних і комунікаційних технологій відкриває нові перспективи і можливості для навчання хімії й передбачає застосування їх на різних етапах уроку: для проведення хімічної розминки, на етапі пояснення нового матеріалу, для корекції знань, умінь, навичок. Інформаційні технології роблять уроки яскравими і змістовними, розвивають пізнавальні здібності учнів і їх творчі сили. Найчастіше всі методологічні завдання у вивченні хімії розв’язуються через технологію мультимедійних уроків. [7]. Завдяки анімації, звуковим і динамічним ефектам, навчальний матеріал стає таким, що легко запам'ятовується і засвоюється. Реалізація комп'ютерних програм на уроках хімії дозволяє побачити те, що часто на звичайному уроці є неможливим: змоделювати хімічний процес, провести небезпечну реакцію.

Учні мають можливість брати активну участь у створенні таких уроків (пошук і систематизація інформації), тим самим, формуючи навички самостійної роботи 3 предмета, а також навички володіння інформаційними комп'ютерними технологіями. Під час підготовки до уроків учні можуть використовувати Інтернет-ресурси, освітні сайти як інформаційне поле для отримання додаткової оперативної, актуальної інформації за темою [7].

Комп'ютерні телекомунікації - це засіб навчання, а також і особлива форма спілкування. Особливістю телекомунікаційних технологій навчання $€$ їх багатофункціональність, оперативність, продуктивність, насиченість, можливість швидкої та ефективної творчої самореалізації учнів, наявність для них персональної освітньої траєкторії. Освітні проекти для школярів засобами комп'ютерних 
телекомунікацій у мережі Інтернет дозволяють учням вибирати навчальний предмет за інтересом, потребою. Беручи участь у дистанційних заходах, учні вибудовують свою індивідуальну траєкторію навчання, а олімпіади, конкурси i проекти допомагають визначитись 3 вибором профілю для подальшого навчання. Важливими мотивами участі в телекомунікаційних освітніх проектах є: можливість самореалізації, оцінка власних сил, знайомство 3 новими формами організації навчальної діяльності [4].

Отже, використання комп'ютерних технологій забезпечує підсилення інтенсивності уроку, дозволяє вчителеві підвищити темп уроку, допомагає краще засвоїти логіку міркувань, ефективно здійснювати перевірку засвоєних знань. Усе це підвищує рівень навчання і викликає інтерес учнів до предмета.

Неабияку роль у процесі вивчення хімії в профільній школі відіграє інтеграція як засіб упровадження нових педагогічних технологій.

Слід зазначити, що не завжди учні співставляють відомості про зовнішній світ, отримані на одному уроці, з інформацією про ті ж обє'кти на інших уроках. Досить часто вони не пов'язують воєдино і розрізнені факти, що демонструються в рамках одного предмета.

У зв'язку з цим постають завдання:

- допомогти учням засвоїти всю сукупність фактів і явищ щодо формування загальної картини світу;

• ліквідувати роз'єднаність шкільних предметів;

• викликати інтерес учнів до навчання;

• підвищити практичну спрямованість навчання [13].

Для розв’язання цих завдань застосовується інтегративна технологія, що здійснюється через міжпредметні зв'язки або інтегровані уроки. Методика використання міжпредметних зв'язків передбачає залучення на уроки 3 одного предмету понять, образів, уявлень з інших предметів. Під час вивчення хімічної науки найтісніше простежуються міжпредметні зв'язки хімії 3 математикою, біологією, фізикою і географією, тобто предметами природничо-математичного циклу.

Досить цікавим є привнесення в сучасний урок хімії літературних уривків, загадок або віршів, оскільки це надає матеріалу, що вивчається, особливу привабливість і викликає творчий інтерес учнів. Використання ж різноманітних 
літературних жанрів у вивченні нового матеріалу розвиває логічне мислення учнів, а також сприяє їх евристичній діяльності на уроці.

Для організації успішної навчальної діяльності учнів можна практикувати систему запитань, які ставить учитель учневі або учень один одному, вибрати девіз або епіграф уроку, що зосереджує увагу на основному, інсценізувати явище чи подію за сюжетом з підручника, використати вірш або уривок, скласти оповідання про елементи і їхні сполуки, пригадати ситуації з кінофільмів, телепередач чи рекламних роликів [9].

Одним із засобів міжпредметних зв'язків $\epsilon$ використання на уроках $\mathrm{i}$ в позакласній роботі оповідань-задач з хімії, у яких інтегруються хімічні й екологічні знання. Складання учнями таких задач сприяє активізації їхньої уваги i спостережливості, розвитку творчих здібностей, формування наукового світогляду.

Проведення інтегрованих уроків створює умови для використання в обговоренні навчальної теми різноманітних завдань, що сприяють розвитку інтересу учнів до предмета.

Інтегровані уроки дають змогу підвищувати рівень знань учнів, розвивають творчу фантазію, збагачують їхню мову, підвищують ерудицію, виховують культуру і смак.

Здебільшого використовуються три типи інтегрованих уроків:

- урок вивчення нового матеріалу;

- урок узагальнення і закріплення вивченого;

- урок контролю знань.

Так, для узагальнення знань 3 органічної і неорганічної хімії доцільним $\epsilon$ проведення інтегрованого уроку «Хімія. Колір. Психологія», метою якого є:

- вивчення кольору з погляду хімії і психологічного впливу;

- створення умов для актуалізації в структурі знань наукових фактів, понять, законів, теорій;

- сприяння усвідомленню учнями соціальної, практичної й особистісної значущості пропонованого навчального матеріалу.

Отже, методи і засоби технології інтегративного навчання у разі активного їх застосування на уроках хімії сприяють академічним досягненням учнів, кращому 
сприйняттю ними дивертисивних оточень, а також $є$ лише одним із багатьох підходів конструктивістського навчання.

Серед інноваційних педагогічних засобів i методів, що забезпечують індивідуалізацію профільного навчання, особливе місце займає проектування як основний вид навчальної діяльності, тобто метод проектів. Під методом проектування слід розуміти узагальнену модель певного способу досягнення мети, систему прийомів, навчальну технологію пізнавальної діяльності.

Проект - це учнівська самодіяльність, конкретна практична творча справа, поетапний рух до мети, прийнятої й усвідомленої учнем. Суть проектної технології полягає у функціонуванні цілісної системи дидактичних засобів (змісту, методів, прийомів тощо), що адаптує навчально-виховний процес до структурних i організаційних вимог навчального проектування. Проектна технологія принципово відповідає за встановлення міцного зворотного зв'язку між теорією і практикою в процесі навчання, виховання і розвитку особистості учня. Отже, метод проектів реалізує головний сенс і призначення навчання - створює умови для співпраці в співтоваристві дослідників і тим самим допомагає учневі стати талановитим.

Найбільш перспективними видами проектної діяльності 3 огляду на iї потенційні психолого-педагогічні можливості є колективні міжпредметні проекти, які виступають не лише як інтегруючий і систематизуючий фактор сучасної освіти, а й забезпечують максимальне ii наближення до реальних потреб життя, творчої самореалізації , природовідповідного розвитку учнівської особистості $[4,9]$.

У практиці навчання хімії проектна діяльність реалізується через:

- урок чи практичне заняття;

• позаурочну діяльність (предметна діяльність);

• науково-практичну діяльність учнів (захист рефератів).

Прикладом можуть бути далі розглядувані проекти.

- Інформаційні проекти дають змогу навчити учнів здобувати й аналізувати інформацію. Учні вивчають і використовують різні методи отримання інформації (література, бібліотечні фонди, ЗМІ, бази даних), іiі обробки (аналіз, узагальнення, зіставлення з відомими фактами, аргументовані висновки) і презентації. Такі проекти є систематичними на уроках хімії. (11 клас: «Хімія та фармакологія»). Форма подання результатів різна: відеофільм, репортаж, мультимедійна презентація тощо. 
- Дослідницькі проекти будуються так: визначення потреби дослідження, означення вимог до об'єкта проектування, формування первинних ідей, їх аналіз, планування, створення, оцінювання (рефлексія). (Наприклад, 11 клас: «Що бачать в одному явищі природи хімік, фізик, поет, художник, музикант?», «Хімія і проблеми створення нових матеріалів з певними властивостями»). Форма подання результатів твір, виставка малюнків, фотографій, свято.

- Прикладні проекти: документи, створені за результатами дослідження; дидактичний матеріал; довідковий матеріал; опорні конспекти; презентація до уроку.

Отже, підготовка і захист проектів $є$ формою діяльності, котра ідеально відповідає практичному шляху здобуття навчального і соціального досвіду, активного залучення і реалізації життєвих планів особистості в умовах профільного навчання [2].

Освітню ж рефлексію учнів можна відстежити, скориставшись однією 3 творчих форм рефлексії - сінквейном. Цей метод полягає у здатності резюмувати інформацію, відтворювати складні ідеї, почуття і подавати їх декількома словами. Він вимагає серйозної, вдумливої рефлексії, що базується на широкому інтелектуальному запасі.

Сінквейн - це вірш, який вимагає синтезу інформації і матеріалу в коротких висловах. Слово сінквейн походить від французького, що означає «п'ять». Отже, сінквейн - це вірш, що складається з п'яти рядків.

Правила написання сінквейна:

• у першому рядку тема називається одним словом (іменником);

- другий рядок - це опис теми у двох словах (двома прикметниками);

- третій рядок - це опис дії в рамках цієї теми трьома словами (дієслова).

- четверта рядок - це фраза з чотирьох слів, що показує відношення до теми (почуття однією фразою);

• останній рядок - це синонім з одного слова, який повторює суть теми.

Наприклад, під час узагальнення теми «Оксигеновмісні органічні сполуки» можна провести інтегрований урок з біологією й екологією. Окремі оксигеновмісні органічні сполуки можна розглядати як природні полімери. Рефлексія такого уроку проводиться у формі сінквейна, наприклад:

1. Вуглеводи. 
2. Оксигеновмісні, органічні.

3. Живлять, одягають, захищають.

4. Природно утворюються методом фотосинтезу.

5. Полісахариди [10].

Отже, виважене і професійне застосування різноманітних інноваційних методів і прийомів для досягнення певних дидактичних цілей надає уроку хімії особливої ефективності, а також $є$ одним із способів розвитку пізнавальних і творчих інтересів учнів до хімії як науки в рамках конструктивістського профільного навчання, що передбачає активізацію працездатності, посилення інтересу до здобуття нових знань, підготовку до розв' язування актуальних життєвих проблем.

Висновки. Отже, розвиток педагогічної науки пропонує учителям і учням нові форми комунікації, нові підходи до розв'язування абстрактних і конкретних завдань, перетворюючи вчителя з авторитарного транслятора готових ідей на координатора інтелектуального і творчого потенціалу учня. Майбутнє за системою навчання, що вкладалася б у схему учень - технологія - вчитель, за якої викладач перетворюється на педагога-методолога, технолога, а учень стає активним учасником процесу навчання. Отже, педагогічні технології, побудовані на суб'єкт-суб'єктній взаємодії, стають визначальними, диктують постійний пошук і виступають обов'язковою умовою реалізації принципу відкритості освітньої системи профільної школи.

Перспективою подальших досліджень $є$ пошук і розробка комплексу умов для розвитку творчого потенціалу учнів у процесі навчання хімії в профільній школі, 3 метою формування учня нового типу, що володіс набором умінь i навичок самостійної роботи, озброєний способами конструктивної, цілеспрямованої діяльності, готовий до співпраці і взаємодії, наділений досвідом самоосвіти для успішної реалізації в умовах сучасного світу.

\section{Список використаних джерел}

1. Алексеев H. Г. Проектирование и рефлексивное мышление / Н. Г. Алексеев // Развитие личности. - 2002. - № 2.

2. Бычков А. В. Метод проектов в современной школе / А. В. Бычков. - М., 2000. $-126 c$. 
3. Веденина Т. И. Дифференциация обучения, как важный фактор развития познавательных интересов школьников [Електронний ресурс] / Е. И. Веденина. Режим доступу: http://festival.1september.ru/articles/413417/.

4. Галанов А. Б. Реализация метода проектов средствами компьютерных телекоммуникаций в системе профильного обучения [Електронний ресурс] / А. Б. Галанов. - Режим доступу : http://www.eidos.ru/journal/2006/0723-4.htm.

5. Имакаев В. Р. Образование и ось времени / В. Р. Имакаев // Философия образования и реформа современной школы. - Пермь. - 2002. - № 5.

6. Максимов О. С. Методика викладання хімії : практикум : навч. посіб. / О. С. Максимов. - К. : Вища шк., 2004. - 167 с.

7. Матвеева И. А. Реализация компетентностного подхода посредством технологии метода проектов [Електронний ресурс] / И. А. Матвеева. - Режим доступу : http://festival.1 september.ru/articles/418499/.

8. Муравлева О. И. Инновационные технологии обучения, реализуемые в практике учителей химии [Електронний ресурс] / О. И. Муравлева. - Режим доступу : http://festival.1 september.ru/articles/513604/.

9. Сазоненко Г. С. Педагогічні технології / Г. С. Сазоненко // Шкільний світ. - К., 2009. - 128 с.

10. Селевко Г. К. Энциклопедия образовательных технологий / Г. К. Селевко // НИИ школьных технологий. - М., 2006. - 257 с.

11. Хуторской A. B. Современные педагогические инновации на уроке [Електронний ресурс] / A. В. Хуторской. - Режим доступу : http://www.eidos.ru/journal/2007/0705-4.htm.

12. Хуторской A. В. Педагогическая инноватика: методология, теория, практика : научное издание / А. В. Хуторской. - М. : Изд-во УНЦ ДО, 2005. - 284 с.

13. Червонная O. C. Интеграция как средство внедрения новых педагогических технологий [Електронний ресурс] / О. С. Червонная. - Режим доступу : http://festival.1 september.ru/articles/100263/.

СОВРЕМЕННЫЕ ИННОВАЦИОННЫЕ ПЕДАГОГИЧЕСКИЕ ТЕХНОЛОГИИ НА УРОКАХ ХИМИИ В ПРОФИЛЬНОЙ ШКОЛЕ 
Тукало Мария Дмитриевна, младший научный сотрудник, Институт информационных технологий и средств обучения, Национальная академия педагогических наук Украины, г. Киев, e-mail: maria.tukalo@ mail.ru

\section{Аннотация}

Статья дает характеристику современных инновационных педагогических технологий по способу их применения на уроках химии в профильной школе, раскрывает значение их в учебном процессе с целью оптимизации усвоения и закрепления знаний и умений, применения их для решения конкретных задач, формирования научных убеждений, усиления творческой активности с переходом от познавательной мотивации к профессиональной через создание комплекса условий для развития творческого потенциала учащихся с использованием компьютерно ориентированных средств обучения в рамках современной педагогической системы с целью реализации основных учебных целей: развивающей, информационной, мобилизационной, коммуникативной, исследовательской.

Ключевые слова: компьютерно ориентированные средства обучения, компьютерные телекоммуникации, инновационные педагогические технологии, метод проектов.

\section{MODERN INNOVATIVE PEDAGOGICAL TECHNOLOGY FOR PROFILE SCHOOL CHEMISTRY LESSONS}

Mariya D. Tukalo, junior researcher, Institute of Information Technologies and Learning Tools of the National Academy of Pedagogical Sciences of Ukraine, Kyiv, e-mail: maria.tukalo@mail.ru

\section{Resume}

The article gives a characteristic of modern innovative pedagogical technologies with methods of their use in chemistry lessons at school, it reveals their importance in the learning process to optimize the learning and the knowledge and skills to apply them to solve specific problems of scientific opinion, enhance the creative activity of transition cognitive motivation of the professional through the establishment of conditions for development of the creative potential of students using computer-oriented learning means within a modern educational system in order to fulfill the basic educational goals: developing, information, mobilization, communication, research. 
Keywords: computer-oriented learning materials, computer telecommunications, innovative educational technology, method of project.

Матеріал надійшов до редакції 02.06.2011 p. 